\title{
Evaluation of quality of life in the period of globalization
}

\author{
Zuzana Stofkova ${ }^{1, *}$, Peter Seemann ${ }^{1}$, and Vladimira Binasova $^{2}$ \\ ${ }^{1}$ University of Zilina, Faculty of Operation and Economics of Transport and Communications, \\ Department of Economics, Univerzitna 1, 01026 Zilina, Slovakia \\ ${ }^{2}$ University of Zilina, Faculty of Mechanical Engineering, Department of Industrial Engineering, \\ Univerzitna 1, 01026 Zilina, Slovakia
}

\begin{abstract}
.
Research background: With the rapid development of information technologies, the trend towards the complexity of the concept of quality of life is intensifying. It is rapid economic change, together with globalization, which is leading to relatively significant changes in the quality of life. The article deals with the issue of quality of life $(\mathrm{QoL})$ as a composite phenomenon in order to evaluate the quality of life.

Purpose of the article: Subjective indicators of quality of life are analysed, including partial and overall life satisfaction in the European Union and in Slovakia. An analysis of the subjective quality of life on a representative sample of inhabitants in Zilina self-govening region (ZSK) was carried out.

Methods: The method of e-survey focused on determining the level of subjective quality of life of inhabitants Zilina self-govening region with individual areas influencing their quality of life. In the survey 540 respondents were requested on the satisfaction with individual areas affecting their life in Zilina self-govening region.

Findings \& Value added: The result of the article is a comparison of individual indicators of the subjective quality of life of the Slovak Republic and selected EU member states. The survey of the satisfaction of the inhabitants of the Zilina self-governing region was carried out in February 2020.The evaluation of the results of the e-survey was performed. The aim of the article is to point out of importance of monitoring and evaluation quality of life and for the purpose of higher territorial units, regions nad local governments' decisions.
\end{abstract}

Keywords: quality of life; indicators of quality of life; life satisfaction

JEL Classification: $131 ; H 75 ; I 15$

\footnotetext{
*Corresponding author: zuzana.stofkova@fpedas.uniza.sk
} 


\section{Introduction}

The quality of life in the age of globalization is influenced by many factors. The close relationship with the quality of life has health area, which is currently discussed, but also other areas related to the quality of life, such as economy, environment, social and areas[1]. Quality of life (QoL) is a historically conditioned level of life processes in which man, society reproduces and develops his existence. [2] As a result, quality of life is a broader concept and is not understood only in terms of economics and human living conditions. [3]

According to WHO e quality of life is defined as perception of one's own position in life in the context of culture and value judgments with regard to one's life goals, assumptions, standards and interests. The physical health, a person's mental state, degree of independence, social relationships or the environment affect the quality of life. [4] The multilevel model of quality of life created by Kovac is based on the definition of "quality of life is a personal emotional-cognitive psychoreflexion comparing the reality of one's own life with his ideal". [5] The multidimensional quality of life model includes objective and subjective quality of life indicators, i.e. the University of Toronto Health Promotion Center model. The model of quality of life on the basis of several indicators and its quantification was described also by I. Laluha. [6]

The authors Soltes et al. [7] distinguish aspects of quality: objective quality of life, subjective quality of life, subjective well-being (well-being). [8] In the economic area of quality of life, the parameters of living standards play an important role. The parameters of living standards are measurable through material economic indicators such as income, expenditure, household consumption, gross domestic product, gross national product, household savings and others. [9] However, it was found that this is an insufficient level to explain people's feelings of satisfaction. [10] From a subjective point of view, QoL is influenced by the requirements and expectations of the individual in terms of happiness, the feeling of physical, psychological and social well-being, satisfaction with life recognition, self - actualization, health, emotional satiety $[11,12]$. The subjective aspect of quality of life concerns the general satisfaction of the individual in relation to his personal goals, expectations, interests, values and lifestyle in general. [13] The evaluation of subjective quality of life focuses on three areas: overall satisfaction with life, satisfaction with smaller areas of life, such as family, housing or relationships and factors that affect the subjective feeling of quality of life. [12] The evaluation of the quality of life is carried out by comparing the conditions for life in municipalities and cities, regions or states on the basis of indicators measuring the quality of life. [14] The hybrid version of well-being (HWB) is a philosophically inspired attempt to overcome the weaknesses of both subjective and objective approaches to well-being. [15]

Quality of life indicators are tools through which it is possible to measure quality of life. Only an indicator that is achieved by a certain period of time can be considered as indicator. The index is a summary expression of the indicators used. [16] Social indicators of quality of life are unemployment, poverty, life expectancy, working age, birth rate, income inequality, migration, access to services, housing, transport, education, as well as the quality of the environment. [17] Structural equation models were used to test the influence of the social impacts perceived by the population on their quality of life. [18] Quality of life is related to many other concepts that affect it, such as way of life, lifestyle, standard of living or quality of social processes. The objective dimension of quality of life monitors material security, social living conditions, social status and physical health. It is defined as the sum of the economic, social, health and environmental conditions of the environment that affect human life. The evaluation of the objective quality of life can be seen as the extent to which an individual uses the possibilities of his life. [19] 


\section{Material and methods}

\subsection{Measuring the quality of life}

The practical use of selected indicators represents the evaluation of quality of life. Different measurement of quality of life has a significant impact on the results achieved. There is no uniform way of assessing the quality of life. [20] There are a large number of indices that are used to assess quality of life at national, international or regional level. Among the best known belong the Human Development Idex (HDI), The Better Life Index, Quality of Life Index - Nation Ranking (QLI). The index consists of 6 subindices - health index, education index, well-being index, democracy index, peace index and environmental index. Quality of Life Index - International Living (QLI 2, Quality of Life Index). [12] The Global Index of Social Progress for 2019 ranks Slovakia 35th. It evaluates economic and other factors, such as safety in the country, the availability and quality of health care, etc. In 2019, Slovakia ranked 35th among 149 countries in the world.

The quality of life is measured also in European countries. One of the many quality surveys conducted in the Member States is the European Quality of Life Survey (EQLS), at last 2016. The survey focused on objective circumstances of the lives, on living conditions, education, income, health and work-life balance and also the subjective quality of life, such as the degree of happiness and satisfaction with their lives. The EQLS measures both life satisfaction and happiness on a scale from 1 to 10 . Both measures have remained generally stable over time in the EU overall, with life satisfaction average around 7.0-7.1 and happiness around 7.4-7.5. The overall age pattern of life satisfaction and happiness in the EU is that both measures more or less decrease with age. According to the e-survey, in 2016 the population felt happiest in Denmark reaching 8.1, in Slovakia 7.1. In the area of quality of life, one of the measured factors is also satisfaction with life. The highest satisfaction with life based on the survey was in Denmark (8.2) in 2016, in Slovakia the satisfaction reached 6.4. The health services are also one of the determinants that affect the lives of the population and thus their quality, the satisfaction with health services in the Slovak Republic reached 5.6, the Czech Republic 6.8, Hungary 5.7, Poland 5.4. In the EQLS question on happiness is intended to capture emotional/affective aspects rather than be a cognitive evaluation of life as in the case of the life satisfaction. [21] During pandemics of COVID-19 the highest overall satisfaction with quality of life was achieved in Denmark, Austria or Finland, meanwhile lower satisfaction levels were monitored in Portugal, Hungary and Slovakia, etc., see in Fig.1. [22]

COVID-19 e-survey, carried out by Eurofound to capture the far-reaching implications of the pandemic for the way people live and work across Europe. The findings of the esurvey from the first round reflected emotional distress and financial concern. There is no doubt that the COVID-19 health and economic crisis has had a huge impact on people's mental well-being and hit the citizens directly or indirectly. Young respondents and those out of work having the lowest mental well-being in April 2020, during the early phase of lockdown, when it was reported by $18 \%$ overall, in July $14 \%$ of them. The feeling of job insecurity has a similar association with low mental well-being as unemployment. Respondents' overall outlook on life showed a marked improvement between April and July 2020. The life satisfaction in Europe and happiness increased in period from 6.4 to 6.8 . As a result, life satisfaction by age in July was U-shaped with young (6.6) and older respondents (6.9) being more satisfied than the middle age group (6.4). Young respondents were more optimistic about their future than older respondents. On the other hand, at $58 \%$ they were less likely to feel very positive about themselves than older respondents $(68 \%$ for $65+$ ). Feeling positive about oneself increased with age. Women remained less optimistic about their future than men - this gap widening further between April and July. 
The pandemic affected also the work-life balance of women more than men. The first results from the e-survey already highlighted how the restrictive measures put in place by EU governments - social distancing, school closures and, finally, lockdown - affected young people more than other age groups. [22]

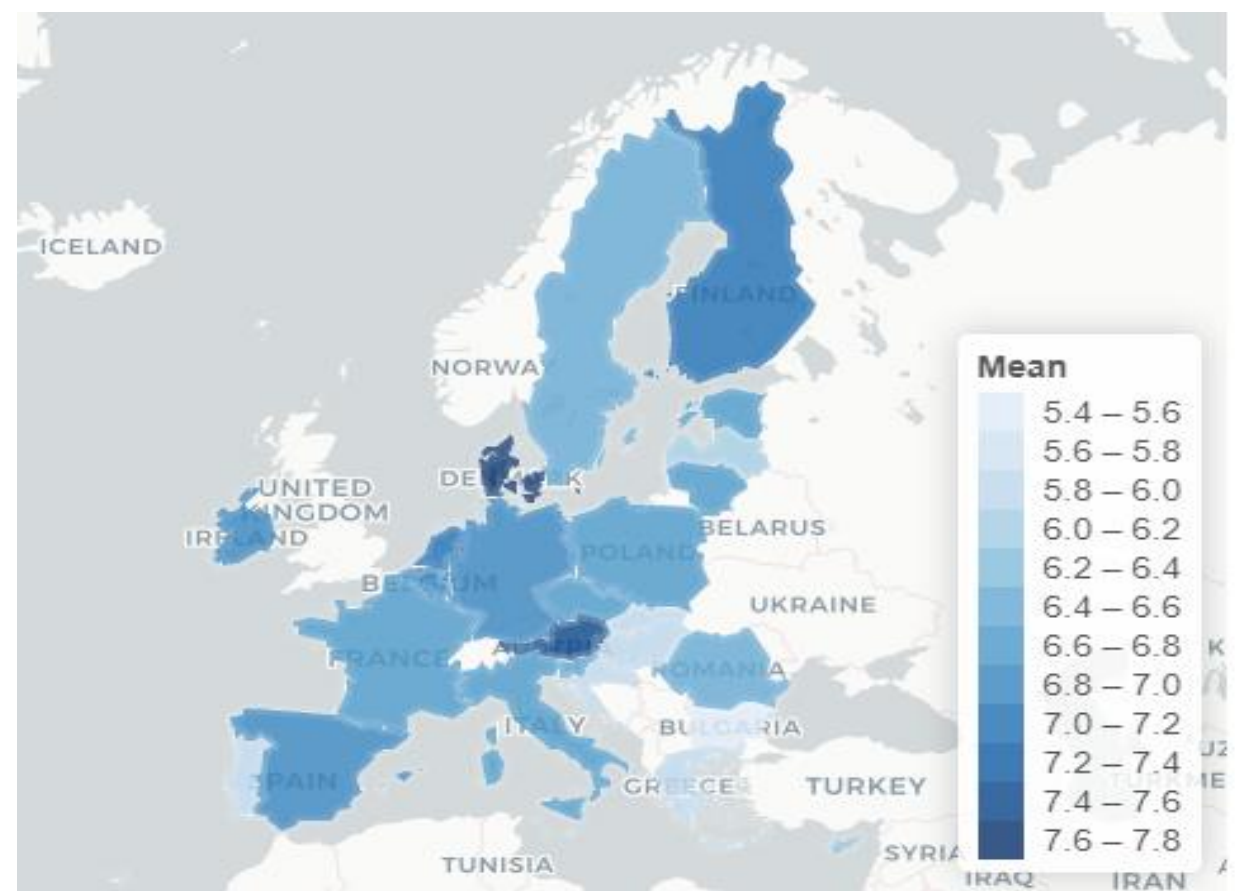

Fig. 1. The overall satisfaction in EU countries during pandemics of COVID-19 [22].

\subsection{Methodology}

Difference in characterizing the quality of life means a variety of approaches to measure the quality of life. The survey was focused on evaluating the quality of life through the satisfaction of respondents living in Zilina self-governing region. The respondents assessed the quality of life from their point of view through questions in a questionnaire.

The subjective view of the quality of life was represented by the issues that affect the quality of life of citizens and the expression of overall satisfaction with the quality of their lives and domains such as, satisfaction with the civic amenities in the surroundings, environmental conditions, health care institutions, transport accessibility, housing opportunities and employment. For these general questions the Likert scale was used: "very dissatisfied", "rather dissatisfied", I can't judge", "rather satisfied","very satisfied". The calculation of satisfaction indices was carried out, too.

The objective indicator of quality of life was represented by the amount of gross monthly income. An e-survey was carried out in the month of February 2020 via electronic questionnaires. The questionnaires were filled in by 540 respondents by $51 \%$ women and representing $49 \%$ men. The sample consisted of six age groups of respondents. The respondents came from 11 districts of the Zilina self-governing region. Regarding the social status of the respondents, all were included in the survey. The educational status among respondents was basic education (19.6\%), secondary education $(52.6 \%)$ and university education $(27.7 \%)$. The probability sampling technique was used by Dermot and Putnam. [23] 


\section{Results}

The overall satisfaction of respondents living in Žilina self-governing region which were satisfied with their quality of life was $80 \%$. According to the respondents, the most influential area of quality of life was health, which was placed at the first place, followed by income, education, career and the environment affecting the quality of life at most. $73 \%$ of repondents were satisfied or very satisfied with the place where they lived. In order to determine the overall satisfaction, tasks aimed at eight domains were requested from 540 respondents. The total number of answers in the given questionnaire according to the relation was calculated.

The total number of answers $=$ (number of tasks $*$ number of respondents) - number of indeterminate answers $=(8 * 540)-350=3970$ answers.

If the questionnaire had a total of 2580 positive answers, the overall satisfaction index was calculated as follows:

$$
\mathrm{I}_{\mathrm{C}}=\frac{\text { Total } \text { number of positive answers }}{\text { Total number of answers }}=\frac{2580}{3970}=0,650
$$

In the survey, a total satisfaction index value of 0.650 was calculated, which has an informative value and the importance is visible in the time period of time and several surveys in particular period. The principle is that a value higher than the initial value will mean a decrease in overall satisfaction as the number of negative responses increases.

The primary goal of local government should be to maintain the value or to ensure the growing tendency of this index, when $\mathrm{I}_{\mathrm{C}}=1$ would mean total satisfaction in all areas. If necessary, the inverse value of the given index can be used also in the form of the $\mathrm{I}_{\mathrm{CN}}$ overall dissatisfaction index. The principle of calculation would be maintained, with the only difference being that the number of negative answers would be given in relation to the total number of answers, i.e. the sum of the answers "dissatisfied" and "very dissatisfied" as follows:

$$
\mathrm{I}_{\mathrm{CN}}=\frac{\text { Total number of negative answers }}{\text { Total number of answers }}=\frac{695}{3970}=0,175
$$

The aim of the municipality is to ensure the decreasing tendency of this index to the value of $\mathrm{I}_{\mathrm{CN}}=0$ (zero dissatisfaction). The partial indices can be calculated also for each domain of life for a better view of improvement in particular domain.

About $70 \%$ of respondents had no problem to find a job in their place of living. The remaining 30\% of respondents had a problem to find work in the place of living. Regarding the distance to work place, $62 \%$ of respondents commuted up to 20 kilometers from their place of living, $24 \%$ of respondents worked up to 50 kilometers and $14 \%$ more than 50 kilometers from their place of living.

About $75 \%$ of respondents were satisfied with the safety in their place of living. $57 \%$ of respondents were satisfied with accessibility and quality of the health care.

Almost $69 \%$ did not plan to change the place of living. The rest of the respondents planned to change their place of residence in the near future due to better housing, insufficient civic amenities, insufficient safety in place of living and dissatisfaction at work.

With the issue of quality of transport infrastructure accessibility $42 \%$ of respondents were dissatisfied, which was due to the lack of motorways. This is associated with other inconveniences such as noise, dust, the risk of accidents and traffic jams. The question about civic amenities turned out relatively well, $78.5 \%$ of respondents were satisfied. Another area focused in e-survey was the possibility of leisure-time activities, where the numbers of satisfied and dissatisfied respondents are almost balanced. 
Concerning environmental sphere 34\% respondents were satisfied, 33\% respondents were dissatisfied with the state of environment - air, water and soil, meanwhile $33 \%$ couldn't judge the situation. According to the results of the survey, the areas which the citizens missed were rest areas, cycling routes and cultural events. The most areas needed to be improved were transport infrastructure, lack of rest areas, greenery, parking places, and polluted environment and lower internet coverage.

The objective indicator included in the satisfaction questionnaire was focused on the gross monthly income of respondents. This question was optional and aimed at respondents who had a regular monthly income. $39 \%$ of the respondents received the minimal wage, 18 $\%$ got a gross salary of over $€ 580$ to $€ 800.21 \%$ of respondents received a gross salary in the range of $€ 800$ to $€ 1,000$. About $10 \%$ of respondents have a gross salary ranging from $€ 1,000$ to $€ 1,200$ and $12 \%$ of respondents had a gross monthly salary above $€ 1,200$.

\section{Discussion}

The subjective well-being has been shown to have a strong correlation with income, age, employment status and health status. Within the EU at country level, life satisfaction correlated with GDP per capita and this correlation was more or less linear. However, for the highest income countries, life satisfaction no longer grows with increasing GDP. Evidence from other research shows the negative impact that unemployment has on life satisfaction, even after controlling for income, trust and mental well-being. Finally, some recent well-being research - such as the World happiness report 2017 - has placed emphasis on the importance of mental health as a key factor in shaping life satisfaction. Good self-reported health is very important for higher life satisfaction. [21]

However, huge economic pressure has been shown to have an impact on a country's average subjective well-being. Apart from satisfaction with life overall, respondents were asked to evaluate their satisfaction with various domains of their life. Of these, life satisfaction correlates most strongly with satisfaction with standard of living. [22]

The analysis performed by Kwarcinski et al. has confirmed that there is a real disparity between the subjective evaluation of well-being and the objective quality of life in the selected European countries. Thus, the quality of life paradox exists, and the Fitting index (FI) can empirically identify it. The research has also shown that the country ranking based on the FI differs from the one created on the basis of GDP per capita. [24] Zhuravleva et al. performed an in-depth analysis concerning smart technologies as catalysts for better health conditions in smart cities. [25] The results could be used also in our region for the improvement of our region.

Based on the survey of quality of life assessment in the Zilina self-governing region, the individual areas on which the survey was focused were evaluated regarding assessment of life satisfaction concerning areas such as employment possibilities, available services, health-care institutions or civic amenities, etc. The areas with which the respondents were dissatisfied was insufficient transport infrastructure, the lack of possibility how to spend their free time, more sports grounds, cycling routes and cultural events.

In the evaluation scale in which the respondents evaluated the areas that affect the quality of their lives at most were the most important values health and income. It is necessary to pay close attention to these issues. Quality of life is the result of the action of objective and subjective conditions. Areas, such as the labour market, the development of science and technology, lifestyle of citizens, provided health-care are factors that have a huge impact on the quality of our lives. 


\section{Conclusion}

The overall satisfaction of respondents living in Žilina self-governing region was $80 \%$. The most important values of quality of life according to the respondents was health, which was placed in the first place, followed by income, the middle value was occupied by education, career and the environment affecting the quality of life. Based on the survey of quality of life assessment in the Zilina self-governing region, several domains focused on the subjective assessment of quality of life were evaluated regarding various spheres of lives of citizens. The areas where the citizens were satisfied, involved place of living, possibilities for services and civic amenities, etc. The areas where the respondents were less satisfied belonged the transport infrastructure, environmental sphere, health-care, etc. Quality of life assessment was carried out via structured questionnaire and calculation of overall indices for satisfaction and dissatisfaction were carried out, too. The purpose of evaluation of the quality of life is to constantly monitor and improve the quality of life at the level of regions or local governments.

The acknowledgement - This paper was supported by project VEGA 1/0755/18, KEGA 043ZU$4 / 2019$

\section{References}

1. Streimikiene, D. (2015). Environmental indicators for the assessment of quality of life. Intellectual Economics, 9(1), 67-79.

2. Antalova, M. (2010). Sociálna kvalita a kvalita pracovného života. Bratislava: Ekonom.

3. Dzuka, J. (2004). Psychologické dimenzie kvality života. Prešov: Prešovská univerzita.

4. Pacione, M. (2003). Urban environmental quality and human wellbeing - a social geographical perspective. Landscape and urban planning, 65(1-2), 19-30.

5. Kovac, D. (2007). Psychológiou k metanoi. Bratislava: Veda.

6. Antalova, M., Laluha I., Př́ivara A. (2013). Kvalita života. Bratislava: Ekonom.

7. Soltes, V., Novaková, B. (2015). Measurement of objective life Quality in the Context of Economically Developed Countries' Quantification. Procedia Economics and Finance, 32, 146-153.

8. Sacks, D., Stevenson, B., Wolfers, J. (2010). Subjective Well-Being, Income, Economic Development and Growth. IZA Discussion Paper, 5230.

9. Hajduova, Z., Andrejovský, P., Beslerová, S. (2014). Development of quality of life economic indicators with regard to the environment. Procedia - Social and Behavioral Sciences, 100, 747-754.

10. Stofkova, J., Stricek, I., Stofkova, K. (2015). Data analysis in quality management of the network enterprise. Engineering Science and Production Management, 273-278.

11. Kubickova, M., Croes, R., Rivera, M. (2017). Human agency shaping tourism competitiveness and quality of life in developing economies. Tourism Management Perspectives, 22(22), 120-131.

12. Hermanova, E. (2012). Koncepty, teorie a meření kvality života. Praha: Sociologické nakladatelství.

13. Solcova, I., Kebza, V. (2004). Kvalita života v psychológií: Osobní pohoda (well being), její determinanty a prediktory. In H. Hnilicová (Ed.), Proceedings of the conference Kvalita života (pp. 21-31). Třeboň: Institut zdravotní politiky a ekonomiky. 
14. Binda, J., Repkova Stofkova, K. (2017). Impact of information and communication technologies on improving the quality and effectiveness of the education process. In L. G. Chova, A. L. Martinez \& I. C. Torres, Proceeding of the 11th International Conference on Technology, Education and Development (pp. 6916-6923). Valencia, INTED Proceedings.

15. Zhulega, I. A., Gagulina, N. L., Samoylov, A. V., Novikov, A. V. (2019). Problems of corporate economics and sustainable development in the context of the sanction world order: Living standards and live quality. Ekonomicko-manazerske spektrum, 13(1), 8395.

16. Antalová, M., Chinoracká, A. (2014). Impulzy pre politiku vzdelávania smerom k znalostnej spoločnosti. Aktuální otázky sociální politiky -teorie a praxe, 8(2), 6-22.

17. Soltes, V., Repkova Stofkova, K. (2019). The impact of education funding on the socioeconomic development of regions. In L. G. Chova, A. L. Martinez \& I. C. Torres, Proceedings o the 12th Annual International Conference of Education, Research and Innovation (ICERI) (pp. 10950-10955). Seville: ICERI Proceedings.

18. Gonzalez D. A., Macias R. A. (2020). Influence of VFR Tourism on the Quality of Life of the Resident Population. Journal of Tourism and Services, 20(11), 60-73.

19. Holková,V., Veselovská, A. (2019). Teoreticko-praktické aspekty formovania kvality života z pohl'adu spotreby. Economic Review/Ekonomické rozhl'ady, 48(3), 237-254.

20. Ira, V., Andrasko, I. (2007). Kvalita života z pohl'adu humánnej geografie. Geografický časopis: časopis Geografického ústavu Slovenskej akadémie vied, 59(2), 159-179.

21. Eurofound. (2017). European Quality of Life Survey 2016: Quality of life, quality of public services, and quality of society, Publications Office of the European Union, Luxembourg.

22. Eurofound. (2020). Living, working and COVID-19, COVID-19 series, Publications Office of the European Union, Luxembourg.

23. Putnam, D., Kovacova, M., Valaskova, L., Stehel, V. (2019). The Algorithmic Governance of Smart Mobility: Regulatory Mechanisms for Driverless Vehicle Technologies and Networked Automated Transport Systems, Contemporary Readings in Law and Social Justice 11(1), 21-26.

24. Kwarcinski, T., Ulman, P. (2020). Quality of Life Paradox. Well-Being Ranking of the Selected European Countries Based on Hybrid Well-Being Approach. Economics \& Sociology, 13(2), 160-180.

25. Zhuravleva, N., Nica, E., Durana, P. (2019). Sustainable Smart Cities: Networked Digital Technologies, Cognitive Big Data Analytics, and Information Technologydriven Economy, Geopolitics, History, and International Relations 11(2), 41-47. 